\title{
A PRELIMINARY REPORT ON AN IRON-RICH FORMATION NEAR RAAHE IN THE GULF OF BOTHNIA, FINLAND
}

\author{
KAI HYTÖNEN \\ Geological Survey of Finland, Otaniemi
}

ABSTRACT

In the Gulf of Bothnia, W of Raahe, there is an iron-rich formation which consists of two portions: an upper oxidized and a lower unoxidized portion. An average sample of the latter contains 35.9 percent Fe. About one half of this iron is included in magnetite, the rest enters into iron-rich clinoamphiboles, clinopyroxene and fayalite. As main minerals the oxidized portion contains iron-rich clinoamphiboles, iron-rich vermiculites and magnetite.

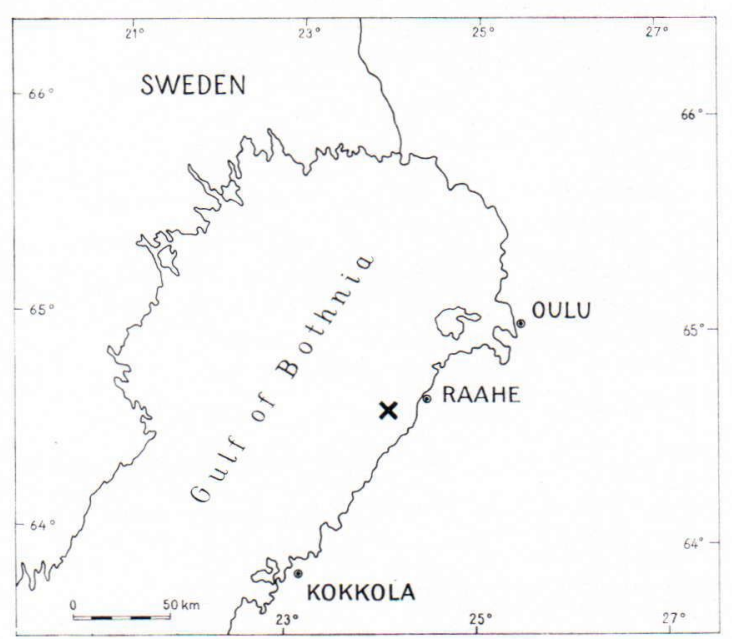

FIG. 1. Map showing the location of the iron-rich formation (X) west of Raahe.

\section{Introduction}

On the nautical maps of the Gulf of Bothnia, a magnetic anomaly is indicated in front of the town of Raahe (Fig. 1). The Otanmäki Company investigated this anomaly aeromagnetically and under conditions of the exceptionally severe winter of 1966 by drilling four drill holes into the aeromagnetically anomalous area. According to these investigations (Nuutilainen and Talvitie, 1967) approximately $25 \mathrm{~m}$ of water and $10 \mathrm{~m}$ of recent sediments (sand and gravel) cover the Precambrian basement rock, which contains an iron-rich formation in mica schist. Fig. 2 indicates the magnetic anomaly of the formation.

According to an agreement made with the Otanmäki Company, the present author studied the drill cores. The results of this preliminary study are presented on the following pages. The author expresses his gratitude to Mr. Heikki Paarma, the chief geologist of the Otanmäki Co., to Messrs. Jouko Talvitie and Erkki Vornanen, geologists of the same company, for placing the drilled material at the disposal of the author, and also for the many fruitful discussions.

\section{Chemistry}

The formation has a dip of about $70^{\circ} \mathrm{NW}$. The upper contact against mica schist is distinct but not very sharp and is fractured. Below the iron-rich bed, quartz-feldspathic schists are more abundant than mica-schist. The thickness of the iron-rich bed is approximately 50 meters. 


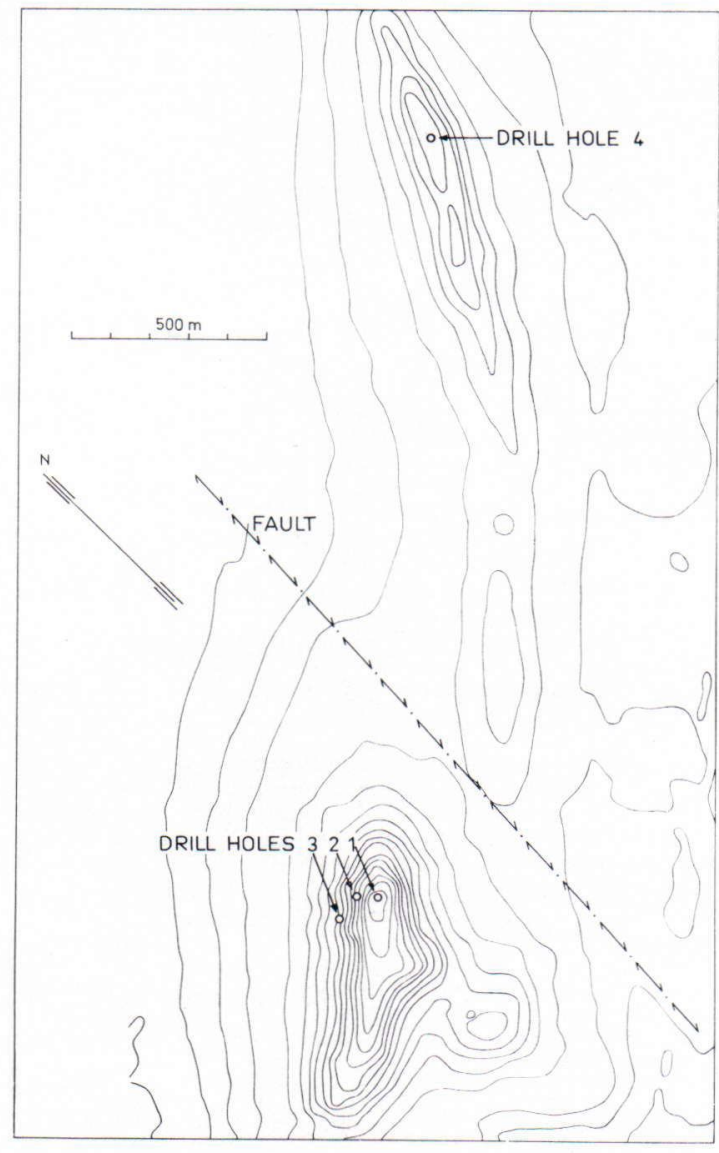

FIG. 2. Vertical-intensity magnetic map of the iron-rich formation west of Raahe, Gulf of Bothnia. According to Nuutilainen and Talvitie, 1967.

The iron-rich formation can be divided into two main portions: the upper oxidized, to a depth of approximately $40 \mathrm{~m}$, and the lower unoxidized continuing for at least $150 \mathrm{~m}$ downwards from the oxidized portion. The rocks of these two portions differ from each other. In Table 1 the chemical analyses and specific gravities are given of rocks from four different parts of the iron-rich bed. Analyses 1, 2 and 3 represent the oxidized rocks with high contents of ferric iron and high rations of $\mathrm{Fe}^{3+}$ to $\mathrm{Fe}^{2+}$, whereas in analysis 4 , the unoxidized rock, these are low.
In Table 2 the magnetite-contents and specific gravities of various parts of the iron-rich formation are listed. The average magnetite content of the oxidized rock is ca. 11 wt. percent. The ferric iron contents of the oxidized rocks, analyses 1, 2 and 3 (Table 1), however, would allow much higher magnetite contents, approximately 34, 20 and 35 wt. percent, respectively. Microscopical observations reveal that also the hematite contents are usually rather low. Thus it is abvious, that part of the $\mathrm{Fe}_{2} \mathrm{O}_{3}$ in the oxidized rocks must be incorporated into the silicate minerals, although the silica contents of these rocks are quite low.

The relations are different for the unoxidized rock. It is obvious that practically all the ferric iron in analysis 4 , Table 1 , is in magnetite. The remaining high $\mathrm{FeO}$ is incorporated in the silicate minerals. According to Nuutilainen and Talvitie (1967) an average sample of the whole unoxidized portion of drill core No. 2 contains 18.1 percent magnetite and 35.9 percent $\mathrm{Fe}$. Thus, after subtracting the magnetite-iron, there remains 22.8 percent $\mathrm{Fe}$ (or $29.3 \% \mathrm{FeO}$ ) for the other minerals of the rock. In addition to magnetite and iron the analysis of the average sample gave the following percentages: $\mathrm{TiO}_{2}$ 0.06, V 0.014, Mn 0.03, P 0.037, S 0.32, Cu 0.04, Zn 0.004, Co 0.002, Ni 0.002 Cr 0.003.

There are also other distinct differences in the chemistry of the two main groups: the oxidized types show relatively high contents of $\mathrm{Al}_{2} \mathrm{O}_{3}$, $\mathrm{MgO}$ and $\mathrm{H}_{2} \mathrm{O}$, whereas in the unoxidized type these oxides are much lower. The specific gravities of the oxidized rocks are clearly lower than those of the unoxidized (Tables 1 and 2).

Chemically this iron-rich bed may be compared with the iron ores of Lake Superior, which contain iron-rich silicates such as minnesotaite, grünerite, stilpnomelane etc. (Tyler, 1949). These ores, however, are conspicuously quartz-bearing, as are also the banded grünerite-bearing iron ores of Western Australia (Miles, 1943). Among the unmetamorphic rocks there are examples whose chemical composition bears a close resem- 
TABLE 1.

Chemical analyses and specific gravities of four specimens along drill corc 1 of the iron-rich formation west of Raahe, Gulf of Bothnia. Analyst: P. Ojanperä; for $\mathrm{Rb}_{2} \mathrm{O}, \mathrm{SrO}, \mathrm{ZrO}_{2}$ and $\mathrm{BaO}: \mathrm{V}$. Hoffrén. The depths indicated are from the sea level.

\begin{tabular}{|c|c|c|c|c|c|c|}
\hline & $\begin{array}{c}1 \\
\text { between } 41.0 \\
\text { and } 41.6 \mathrm{~m}\end{array}$ & $\begin{array}{c}2 \\
\text { between } 52.5 \\
\text { and } 53.0 \mathrm{~m}\end{array}$ & $\begin{array}{c}3 \\
\text { between } 61.2 \\
\text { and } 61.8 \mathrm{~m}\end{array}$ & $89.6 \mathrm{~b}$ & $\frac{\mathrm{n}}{\mathrm{n}} .95 \mathrm{~m}$ & \\
\hline $\begin{array}{l}\mathrm{SiO}_{2} \ldots \ldots \ldots \ldots \ldots \\
\mathrm{TiO}_{2} \ldots \ldots \ldots \ldots \ldots \\
\mathrm{Al}_{2} \mathrm{O}_{3} \quad \ldots \ldots \ldots \ldots \ldots \\
\mathrm{Fe}_{2} \mathrm{O}_{3} \ldots \ldots \ldots \ldots \ldots \\
\mathrm{FeO} \ldots \ldots \ldots \ldots \ldots\end{array}$ & $\begin{array}{r}27.63 \\
0.37 \\
6.30 \\
23.21 \\
18.55\end{array}$ & $\begin{array}{r}32.89 \\
0.42 \\
8.00 \\
14.00 \\
19.03\end{array}$ & $\begin{array}{r}36.58 \\
0.25 \\
4.44 \\
23.98 \\
13.19\end{array}$ & $\begin{array}{r}56.08 \\
0.04 \\
0.81 \\
5.39 \\
27.63\end{array}$ & $\begin{array}{l}\text { weight n } \\
\mathrm{Q} \\
\mathrm{ab} \\
\text { or } \\
\text { an }\end{array}$ & $\begin{array}{r}25.4 \\
1.4 \\
0.5 \\
1.2\end{array}$ \\
\hline $\begin{array}{l}\mathrm{MnO} \ldots \ldots \ldots \ldots \\
\mathrm{MgO}\end{array} \ldots \ldots \ldots \ldots$ & $\begin{array}{l}0.13 \\
9.29\end{array}$ & $\begin{array}{r}0.07 \\
11.97\end{array}$ & $\begin{array}{l}0.06 \\
8.45\end{array}$ & $\begin{array}{l}0.06 \\
2.01\end{array}$ & Salic & 28.5 \\
\hline $\begin{array}{l}\mathrm{MgO} \ldots \ldots \ldots \ldots \ldots \ldots \\
\mathrm{CaO} \ldots \ldots \ldots \ldots\end{array}$ & 3.39 & 2.50 & 3.43 & 5.62 & $\mathrm{CaSiO}_{3}$ & 10.3 \\
\hline $\mathrm{Na}_{2} \mathrm{O} \ldots \ldots \ldots \ldots$ & 0.26 & 0.36 & 0.32 & 0.16 & $\mathrm{MgSiO}_{3}$ & 5.0 \\
\hline $\mathrm{K}_{2} \mathrm{O} \ldots \ldots \ldots \ldots$ & 0.38 & 0.42 & 0.34 & 0.08 & $\mathrm{FeSiO}_{3}$ & 45.3 \\
\hline $\mathrm{P}_{2} \mathrm{O}_{5} \quad \ldots \ldots \ldots \ldots$ & 0.19 & 0.25 & 0.28 & 0.09 & $\mathrm{mt}$ & 7.8 \\
\hline $\mathrm{CO}_{2} \ldots \ldots \ldots \ldots$ & 1.94 & 0.00 & 0.00 & 0.24 & il & 0.1 \\
\hline $\mathrm{H}_{2} \mathrm{O}+\ldots \ldots \ldots \ldots$ & 6.63 & 7.69 & 4.66 & 1.27 & ap & 0.2 \\
\hline $\mathrm{H}_{2} \mathrm{O}-\cdots \cdots \cdots$ & 1.76 & 2.33 & 2.98 & 0.05 & pr & 0.8 \\
\hline $\mathrm{s} \ldots \ldots \ldots \ldots$ & 0.00 & 0.00 & 0.02 & 0.43 & $\mathrm{cc}$ & 0.6 \\
\hline$C \ldots \ldots \ldots \ldots \ldots$ & 0.16 & 0.42 & 1.33 & 0.55 & graph. & 0.6 \\
\hline $\mathrm{Rb}_{2} \mathrm{O} \ldots \ldots \ldots \ldots$ & 0.00 & 0.00 & 0.00 & 0.00 & Femic & 70.7 \\
\hline $\mathrm{SrO} \ldots \ldots \ldots \ldots$ & 0.005 & 0.005 & 0.005 & 0.005 & Rest & 1.3 \\
\hline $\mathrm{ZrO}_{2} \ldots \ldots \ldots \ldots$ & 0.00 & 0.00 & 0.00 & 0.00 & & \\
\hline $\mathrm{BaO} \ldots \ldots \ldots \ldots$ & 0.01 & 0.01 & 0.01 & 0.01 & & \\
\hline $\begin{array}{l}\text { Total .. } \\
\text { Sp.gr. . }\end{array}$ & 100.205 & 100.365 & 100.325 & 100.525 & & \\
\hline Sp.gr. . . . . . . & 2.88 & 2.90 & 2.85 & 3.33 & & \\
\hline
\end{tabular}

TABLE 2.

Magnetite contents and specific gravities of various parts of the iron-rich formation west of Raahe, Gulf of Bothnia

\begin{tabular}{|c|c|c|}
\hline & $\begin{array}{l}\text { Magnetite } \\
\text { content } \\
\text { wt. } \%\end{array}$ & Sp. gr. \\
\hline \multicolumn{3}{|l|}{ Oxidized portion } \\
\hline 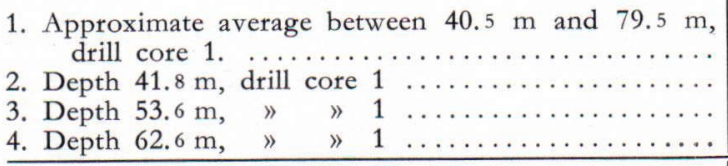 & $\begin{array}{c}11 \\
6.9 \\
0.4 \\
6.2 \\
\end{array}$ & $\begin{array}{l}2.79 \\
2.78 \\
3.10 \\
\end{array}$ \\
\hline \multicolumn{3}{|l|}{ Unoxidized portion } \\
\hline $\begin{array}{l}\text { 5. Average between } 83.9 \mathrm{~m} \text { and } 150.25 \mathrm{~m} \text {, drill core } 2 \text {. } \\
\text { 6. Depth } 91.6 \mathrm{~m} \text {, drill core } 1 \ldots \ldots \ldots \ldots \ldots \ldots \ldots\end{array}$ & $\begin{array}{r}18.1 \\
1.7\end{array}$ & $\begin{array}{l}3.65 \\
3.34\end{array}$ \\
\hline
\end{tabular}

1. Visual microscopic estimate, on 39 thin sections.

2, 3, 4 and 6. Determined from susceptibility values: 1 vol. $\% \mathrm{Fe}_{3} \mathrm{O}_{4} \rightarrow \mathrm{k}=3000 \cdot 10^{-6}$ c.g.s. (Measured by H. Kumpunen).

5. From Nuutilainen and Talvitie, 1967. 
TABle 3.

Chemical analyses of Huronian ferriferous mudstone, Iron County, Michigan (Pettijohn, 1949, p. 287) and of mica schist occurring above the iron-rich formation west of Raahe, Gulf of Bothnia, drill core 3, depth $83 \mathrm{~m}$ (analyst: P. Ojanperä; for $\mathrm{Rb}_{2} \mathrm{O}, \mathrm{SrO}, \mathrm{SrO}_{2}, \mathrm{BaO}$ : V. Hoffrén).

\begin{tabular}{|c|c|c|}
\hline & $\begin{array}{c}1 \\
\text { Mudstone } \\
\text { Iron County }\end{array}$ & $\begin{array}{c}2 \\
\text { Mica schist } \\
\text { west of Raahe }\end{array}$ \\
\hline 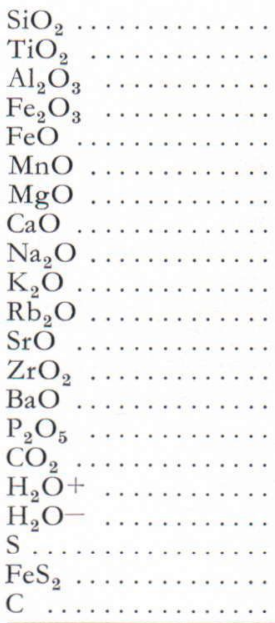 & $\begin{array}{r}52.85 \\
0.60 \\
8.71 \\
\int_{24.03} \\
1.10 \\
2.87 \\
0.10 \\
1.48 \\
1.89 \\
- \\
- \\
0.78 \\
0.20 \\
5.56 \\
0.03 \\
-\end{array}$ & $\begin{array}{r}63.97 \\
0.45 \\
16.62 \\
0.84 \\
4.02 \\
0.07 \\
2.37 \\
1.88 \\
3.11 \\
3.94 \\
0.01 \\
0.04 \\
0.02 \\
0.06 \\
0.09 \\
0.00 \\
1.15 \\
0.08 \\
0.74 \\
0.63\end{array}$ \\
\hline Total $\ldots \ldots \ldots$ & 100.20 & 100.09 \\
\hline
\end{tabular}

blance to the rocks considered in this paper. One such example is the stilpnomelane-bearing Huronian ferriferous mudstone of the Iron County of Michigan (Pettijohn, 1949) (Table 3, column 1).

It is also noteworthy that the mica schist (Table 3, column 2) above the iron-rich bed is chemically of a quite ordinary type.

\section{Petrography and mineralogy}

Unoxidized rock.

According to Nuutilainen and Talvitie (1967) the rock of the unoxidized portion of the ironrich formation is usually dark grey, sometimes almost black and medium to finegrained. The schistosity is relatively distinct. The bedding is most distinct towards the foot, otherwise it is usually indistinct.
Table 4 presents the results of separation experiments and partial chemical analyses on three specimens along drill core No. 2 of the unoxidized iron-rich formation. In these experiments magnetite was extracted from the powdered rock with a Ding David Stupe magnetic separator, the rest of the rock powder being treated with heavy liquids. As is indicated in the last column of Table 4, the fractions obtained are not quite monomineralic. However, the results can be used for the evaluation of the contents of $\mathrm{FeO}$ and $\mathrm{MgO}$ in the silicate minerals of the rock.

The following minerals, listed in their approximate order of abundance, were observed: green clinoamphibole (probably ferroactinolite), colourless clinoamphibole (probably grünerite), magnetite, colourless clinopyroxene (probably hedenbergite), fayalite, quartz, calcite, green and brown mica and garnet (probably almandite, $\mathrm{N}$ ca. 1.795).

Analysis 4, Table 1, represents the composition of a portion of the unoxidized rock, ca. $35 \mathrm{~cm}$ in length. Due to bedding, the relative abundance of the minerals varies intensively within this portion. The modal mineral composition of the portion is not known, but it is obvious that it is not far from that of the three specimens in Table 4, although, it has a higher quartz- and lower magnetite-content. The atom ratio of silicatic $\mathrm{Fe}$ to $\mathrm{Mg}$ - viz. 88 to 12 - is quite close to that of the several silicate-fractions listed in Table 4. The silicatic FeO content is almost as high as in the average sample of drill-core 2 (p. 136). The low $\mathrm{Al}_{2} \mathrm{O}_{3}$ suggests that the amphiboles and pyroxene must be Al-poor.

In the following, some data are given for the four dominating silicate-minerals of the rock:

Green clinoamphibole is the main mineral of the unoxidized portion. In specimens 3084 and 3 095, Table 4, it amounts to ca. 40 and 35 wt. percent, respectively. Pleochroism: X light brown, $\mathrm{Y}$ brownish green, $\mathrm{Z}$ bluish green; absorption: $\mathrm{Z} \approx \mathrm{Y}>\mathrm{X}$. The refractive indices, 
Table 4.

Results of separation experiments and partial chemical analyses on different fractions of three specimens of the unoxidized iron-rich formation along drill core 2. Modified according to Nuutilainen and Talvitie (1967). Heavy liquid separations by E. Vornanen. Fe and $\mathrm{MgO}$ determined by E. Tikkanen.

\begin{tabular}{|c|c|c|c|c|c|}
\hline & Sp. gr. & $\begin{array}{c}\text { Size of } \\
\text { fraction } \\
\%\end{array}$ & $\begin{array}{l}\text { Total Fe } \\
\text { calculated } \\
\text { as } \mathrm{FeO} \\
\text { wt } \%\end{array}$ & $\begin{array}{l}\mathrm{MgO} \\
\mathrm{wt} \%\end{array}$ & Minerals \\
\hline \multirow{7}{*}{$\begin{array}{l}\text { Specimen No. } \\
3084 \\
\text { between } \\
88.60-94.00 \mathrm{~m}\end{array}$} & $>3.1$ & 5.5 & 11.4 & & $50 \%$ mica, the rest quartz and carbonate \\
\hline & & 0.8 & 19.6 & & Over $50 \%$ mica, the rest green amphibole \\
\hline & $3.2-3.3$ & 6.0 & 30.1 & & Over $90 \%$ green amphibole \\
\hline & $3.3-3.4$ & 32.6 & 32.4 & 3.9 & $\begin{array}{l}\text { Over } 90 \% \text { green amphib., the rest colour- } \\
\text { less amphibole }\end{array}$ \\
\hline & $3.4-3.5$ & 21.0 & 35.6 & 3.9 & $\begin{array}{l}\text { Over } 50 \% \text { colourless amphib. the rest } \\
\text { green amphibole + pyroxene. }\end{array}$ \\
\hline & $>3.5$ & $\begin{array}{l}17.2 \\
16.9\end{array}$ & 32.2 & 2.9 & $\begin{array}{l}\text { Principally colourless pyroxene } \\
\text { Magnetite-concentrate containing } 65.7 \% \\
\text { Fe. }\end{array}$ \\
\hline & & 100.0 & & & \\
\hline \multirow{5}{*}{$\begin{array}{l}\text { Specimen } \\
\text { No. } 3086 \\
\text { between } \\
98.45 \text { and } \\
105.36 \mathrm{~m}\end{array}$} & \multirow{4}{*}{$\begin{aligned} &> 3.16 \\
& 3.16-3.3 \\
& 3.3-3.5 \\
&>3.5\end{aligned}$} & 3.7 & 8.0 & & Quartz, carbonate, a little green amphibole \\
\hline & & $\begin{array}{l}11.5 \\
42.6\end{array}$ & 30.9 & $\begin{array}{l}4.0 \\
4.3\end{array}$ & $\begin{array}{l}\text { Green amphibole } \\
\text { Colourless }+ \text { green }\end{array}$ \\
\hline & & 18.6 & 49.4 & 2.8 & Principally colourless \\
\hline & & 23.6 & & & $\begin{array}{l}\text { pyroxene (+some fayalite ?) } \\
\text { Magnetite-concentrate containing } 59.6 \mathrm{Fe} \text {. }\end{array}$ \\
\hline & & 100.0 & & & \\
\hline \multirow{7}{*}{$\begin{array}{c}\text { Specimen } \\
\text { No. } 3095 \\
\text { between } \\
140.39 \text { and } \\
145.70 \mathrm{~m}\end{array}$} & $>3.1$ & 5.2 & 8.4 & \multirow{6}{*}{$\begin{array}{l}4.7 \\
4.7\end{array}$} & Quartz, mica, carbonate \\
\hline & $3.1-3.2$ & 2.3 & 27.6 & & Green mica \\
\hline & $3.2-3.3$ & 4.9 & 28.0 & & $50 \%$ green mica $+50 \%$ green amphibole \\
\hline & $3.3-3.4$ & 27.6 & 31.0 & & $90 \%$ green amphibole \\
\hline & $3.4-3.5$ & 24.3 & 31.9 & & $\begin{array}{l}70 \% \text { colourless amphibole, the rest green } \\
\text { amphib. }\end{array}$ \\
\hline & $>3.5$ & $\begin{array}{r}4.5 \\
31.2\end{array}$ & 49.9 & & $\begin{array}{l}\text { Pyroxene and fayalite } \\
\text { Magnetite-concentrate containing } 57.3 \% \\
\text { Fe. }\end{array}$ \\
\hline & & 100.0 & & & \\
\hline
\end{tabular}

$\alpha \approx 1.680$ and $\gamma \approx 1.704$, for the green amphibole of specimen 3095 , correspond to those of an amphibole with a composition close to the iron end member of the tremolite-ferroactinolite series.

The colourless clinoamphibole in specimens 3084 and 3095 amounts to ca. 15 and 17 wt. percent, respectively. The refractive indices, $\alpha \approx 1.675$ and $\gamma \approx 1.718$, for the colourless amphibole of specimen 3095 , correspond to those of an amphibole of the cummingtonite-grünerite series with ca. 88 mol. percent $\mathrm{Fe}_{7} \mathrm{Si}_{8} \mathrm{O}_{22}(\mathrm{OH})_{2}$ and 12 percent $\mathrm{Mg}_{7} \mathrm{Si}_{8} \mathrm{O}_{22}(\mathrm{OH})_{2}$.

According to Table 4, the ratios of $\mathrm{Fe}$ to $\mathrm{Mg}$ in the clinopyroxene-bearing fractions are almost the same or slightly higher than those listed for the amphibole-fractions. The refractive indices of the clinopyroxene, $\alpha \approx 1.730$ and $\gamma \approx 1.755$ (specimen 3 095), correspond to a fairly ironrich hedenbergite with ca. 95 mol. percent $\mathrm{CaFeSi}_{2} \mathrm{O}_{6}$,

A rough microscopic examination of the pyroxene- and fayalite-bearing fraction gives 1 - 
2 percent fayalite for specimen 3095 . In a thin section, made of a sample from a depth of $91 \mathrm{~m}$ from drill core 1 , the fayalite content exceeds 10 percent. For the fayalite of specimen 3095 $\mathrm{X}$-ray diffraction gave a compostition of $92 \mathrm{~mol}$. percent $\mathrm{Fa}$.

In drill-core No. 1 some vein-like sulphidebearing portions, a few centimetres in width, and containing lamellar pyrrhotite as main mineral were examined by Pentti Ervamaa. One such portion occurs at a depth of $88.3 \mathrm{~m}$ and contains in addition to pyrrhotite, pyrite, marcasite, chalcopyrite and arsenopyrite with inclusions of gold and an unidentified silver mineral.

\section{Oxidized rock.}

The rock of the oxidized portion of the ironrich formation is usually dark grey, almost black, in some places reddish due to hematite. The schistosity is not as distinct as in the unoxodized portion and there is no clear contact-region between the two portions.

The following minerals, listed in their approximate order of abundance, were observed: bluish clinoamphibole, brown vermiculite, green vermiculite, magnetite, unidentified serpentinelike mineral, almandine, colourless clinoamphibole, quartz, calcite, hematite (and goethite ?), graphite, and apatite.

Thin section examination reveals that the rock is often quite turbid due to the abundant pigment (graphite, hematite, goethite). The vermiculite grains are usually smaller $(0.02$ to $0.1 \mathrm{~mm}$ ) than those of the amphiboles and magnetite (up to $0.5 \mathrm{~mm}$ ). The unidentified serpentine-like mineral is extremely fine-grained (under $0.01 \mathrm{~mm}$ ).

The examination of a series of thin sections between $40 \mathrm{~m}$ and $80 \mathrm{~m}$ along drill core 1 reveals that the relative abundance of the minerals varies within the portion. In some of the thin section the amphiboles predominate while the vermiculites are almost completely absent, or vice versa. The amounts of magnetite (Table 2) and quartz also vary. Thus, no quartz was detected in analyzed specimens 1 and 2 (Table 1), whereas in specimen 3 it amounts to ca. 10 percent of the rock. Also the amount of the finegrained unidentified serpentine-like mineral varies. The occurrence of almandine $\left(\mathrm{a}_{0} 11.55 \AA\right.$, $\mathrm{N} \approx 1.813$ ) is mainly limited to the depths between 52 and $53 \mathrm{~m}$ and between 61 and $69 \mathrm{~m}$.

The three analyses 1, 2 and 3 (Table 1) of the oxidized portion also show variations, especially in their $\mathrm{SiO}_{2}$ and iron contents. Due to the inhomogeneity of the rock the modal mineral compositions of the analyzed specimens were not determined.

In the following some data are given for the predominating minerals of the oxidized portion:

The electron probe micro-analyses and formulae for three clinoamphiboles from two thin sections are listed in Table 5. The total iron is expressed as $\mathrm{FeO}$ and the formulae have been calculated on the basis of 23 oxygen atoms. Also the ratios of $(\mathrm{Fe}+\mathrm{Mn})$ to $\mathrm{Mg}$ are given. Of the bluish green amphiboles No. 1 has a composition corresponding to ferrotschermakite and No. 2 to ferrohastingsite. The colourless amphibole (No. 3) is a grünerite. The analyses and formulae deviate somewhat from those commonly observed for amphiboles. The figures of $\mathrm{SiO}_{2}$ (and $\mathrm{Si}$ ) in particular are exceptionally low.

In thin section the amphibole crystals are usually elongated, often in subparallel or radial aggregates. The bluish green variety predominates quantitatively. Pleochroism: $\mathrm{X}$ light brownish yellow or almost colourless, $\mathrm{Y}$ brownish green, $\mathrm{Z}$ bluish green. Absorption: $\mathrm{X}<\mathrm{Y} \approx \mathrm{Z}$. Sometimes the coloured and colourless varieties occur together in subparallel orientation (Figure 3). The colourless amphibole shows a distinctly higher birefringence than the coloured.

The powder diffraction pattern of the bluish green amphibole (column 2, Table 5) is of the type commonly observed for the amphiboles of the hornblende group (ASTM). The colourless 
Table 5 .

Electron probe micro-analyses and formulae for three clinoamphiboles along drill core No. 1 of the oxidized iron-rich formation west of Raahe, Gulf of Bothnia. Analysts: J. Siivola (1) and K. Laajoki (2 and 3).

\begin{tabular}{|c|c|c|c|c|}
\hline & $\begin{array}{l}\text { 1. Bluish green } \\
\text { clinoamphibole } \\
\text { depth } 53.0 \mathrm{~m}\end{array}$ & $\begin{array}{l}\text { 2. Bluish green } \\
\text { clinoamphibole } \\
\text { depth } 73.8 \mathrm{~m}\end{array}$ & $\begin{array}{l}\text { 3. Colourless } \\
\text { clinoamphibole } \\
\text { depth } 73.8 \mathrm{~m}\end{array}$ & \\
\hline 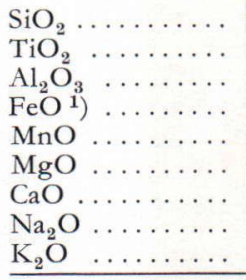 & $\begin{array}{r}34.7 \\
0.0 \\
16.9 \\
29.7 \\
- \\
2.0 \\
11.9 \\
0.0 \\
1.3 \\
\end{array}$ & $\begin{array}{r}30.2 \\
0.5 \\
17.4 \\
34.1 \\
0.1 \\
4.3 \\
12.6 \\
1.6 \\
0.8 \\
\end{array}$ & $\begin{array}{r}38.3 \\
0.1 \\
1.0 \\
48.1 \\
0.2 \\
9.0 \\
0.8 \\
0.2 \\
0.2\end{array}$ & \\
\hline $\begin{array}{l}\mathrm{Si} \ldots \ldots \ldots \\
\mathrm{Al} \ldots \ldots \ldots \ldots \\
\mathrm{Al} \ldots \ldots \ldots \\
\mathrm{Ti} \ldots \ldots \ldots \\
\mathrm{Fe}^{2+}+\mathrm{Mn} \ldots \ldots \\
\mathrm{Mg} \ldots \ldots \ldots \ldots \\
\mathrm{Ca} \ldots \ldots \ldots \\
\mathrm{Na} \ldots \ldots \ldots \ldots \\
\mathrm{K} \ldots \ldots \\
\mathrm{O} \ldots \ldots \ldots\end{array}$ & \begin{tabular}{l|l}
$\begin{array}{l}96.5 \\
5.6 \\
2.4\end{array}$ & 8.0 \\
0.9 & \\
-1 & 5.5 \\
4.1 & \\
0.5 & \\
2.1 & \\
-.3 & 2.4 \\
0.0 & \\
23.0 & \\
\end{tabular} & 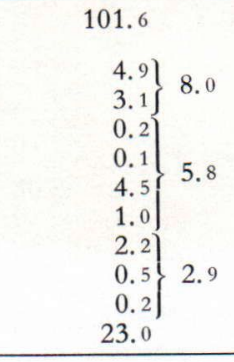 & $\begin{array}{r}97.9 \\
6.6 \\
0.2\} \\
- \\
- \\
7.0 \\
2.3 \\
0.2 \\
- \\
- \\
23.0\end{array}$ & 6.8 \\
\hline $\mathrm{Fe}+\mathrm{Mn}): \mathrm{Mg}$ & $89: 11$ & $83: 17$ & $75: 25$ & \\
\hline
\end{tabular}

1) Total iron

Table 6.

Electron probe micro-analyses and formulae for four vermiculites along drill core No. 1 of the oxidized iron-rich formation west of Raahe, Gulf of Bothnia. Analyst: J. Siivola.

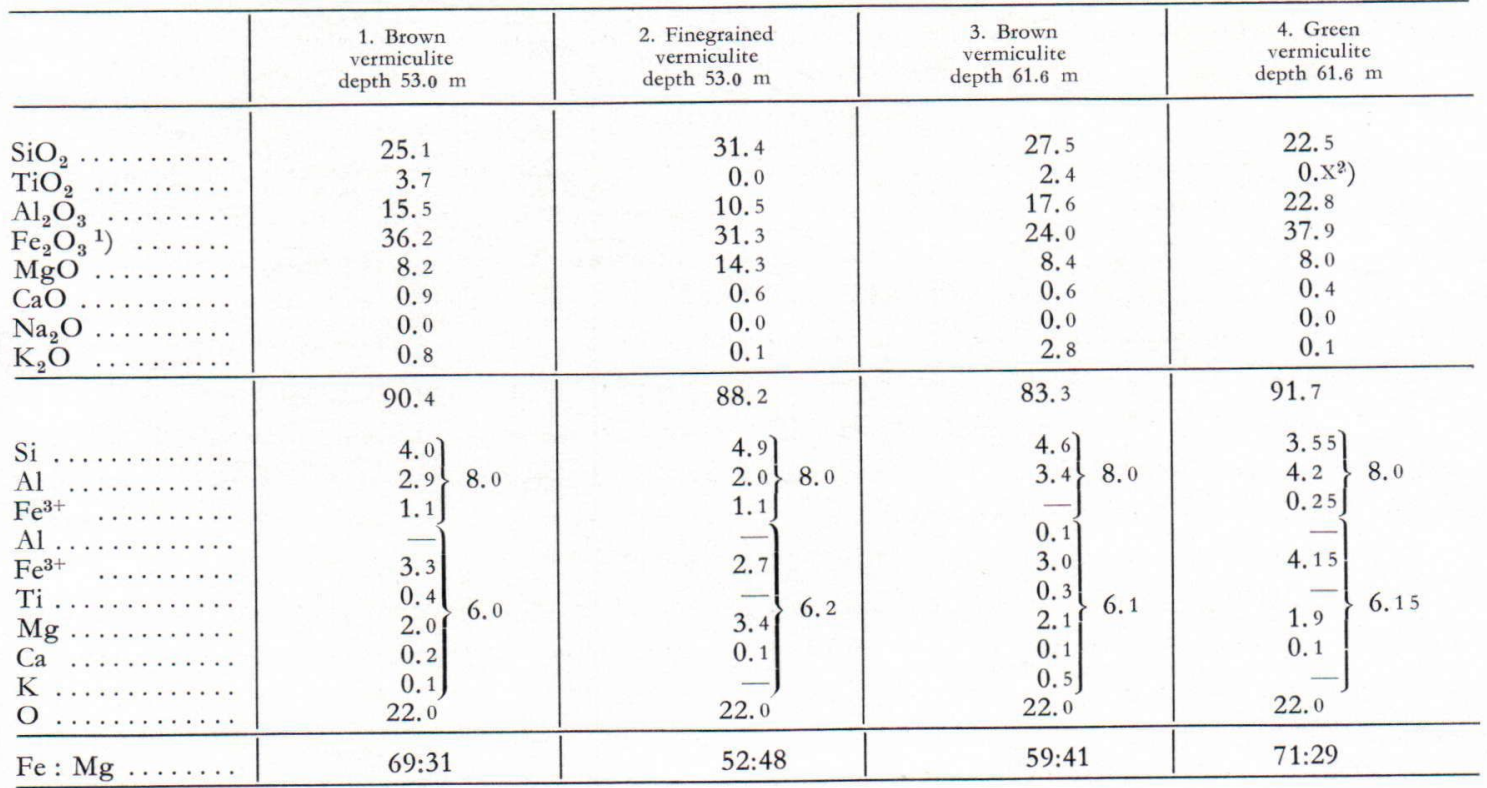

\footnotetext{
1) Total iron

2) Order of magnitude
} 


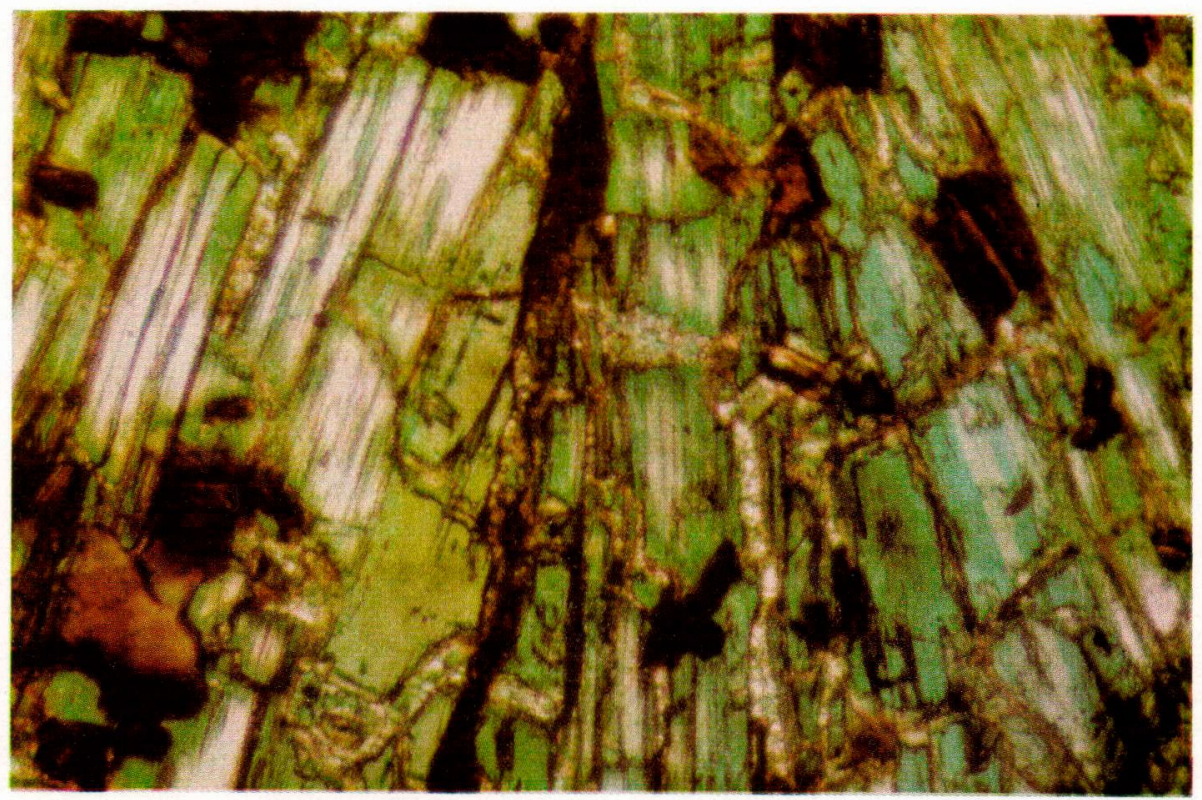

FIG. 3. Thin section photograph of coloured (bluish green and brownish green) and colourless amphiboles as well as some dark brown vermiculite. Oxidized iron-rich formation. Drill core 1, depth $73.8 \mathrm{~m}$. Magnification $120 \times$. Photo E. Halme.

amphibole gives a pattern similar to those of a cummingtonite and a grünite.

In Table 6 electron probe micro-analyses and formulae are listed for four vermiculites from two thin sections. The total iron is expressed as $\mathrm{Fe}_{2} \mathrm{O}_{3}$ and the formulae were calculated on the basis of 22 oxygen atoms ignoring $\mathrm{H}_{2} \mathrm{O}$ which was not determined. Also the ratios of $\mathrm{Fe}$ to $\mathrm{Mg}$ are given. In all four vermiculites Fe predominates over $\mathrm{Mg}$. The oxidation state of iron was not determined. However, in the formulae of Table 6 iron is shown as ferric, because $\mathrm{Fe}^{3}+$ usually predominates over $\mathrm{Fe}^{2}+$ in vermiculites (Deer, Howie and Zussman, 1962). It is obvious, that an essential portion of the relatively high $\mathrm{Fe}_{2} \mathrm{O}_{3}$ in the analyses of the oxidized iron-rich rocks (Table 1) is included in the vermiculites. Also the fairly high contents of $\mathrm{H}_{2} \mathrm{O}+$ and $\mathrm{H}_{2} \mathrm{O}-$ in the rock analyses are mainly due to the vermiculites.

The brown vermiculites ( 1 and 3 ) show unusually high $\mathrm{TiO}_{2}$ contents, and thus resemble some biotites, which often contain appreciable amounts of $\mathrm{TiO}_{2}$. Also $\mathrm{K}_{2} \mathrm{O}$ is quite high in the brown vermiculites.

In thin section the brown vermiculites in particular resemble biotite. They are uniaxial negative, birefringence is almost as strong as in biotite and they show the following pleochroism and absorption: $\mathrm{X}$ light brown $<\mathrm{Y}=\mathrm{Z}$ light greenish brown to brown; X light yellowish brown to brownish red $<\mathrm{Y}=\mathrm{Z}$ dark green (Figs. 4 and 5).

A powder photograph taken with a DebyeScherrer camera shows the following diffraction lines and intensities for the brown vermiculite of analysis 1 (Table 6): 14. (s), 7.15 (s), 4.62 (m), $3.57(\mathrm{~m}), 2.68(\mathrm{w}), 2.58(\mathrm{w}), 2.45$ broad $(\mathrm{w})$, $1.552(\mathrm{~m}), 1.515(\mathrm{w})$. A green vermiculite (drill core 1, depth $46.8 \mathrm{~m}$ ) gave the following powder pattern: 14. (s), 7.2 (s), $4.8(\mathrm{w}), 4.6(\mathrm{w}), 3.59(\mathrm{~m})$, $2.88(\mathrm{w}), 2.66(\mathrm{~m}), 2.60(\mathrm{w}), 2.45$ broad $(\mathrm{w})$, $1.545(\mathrm{~m}), 1.510(\mathrm{w}), 1.330(\mathrm{vw})$. The spacings of 14 and $7 \AA$ disappear after heating for 30 


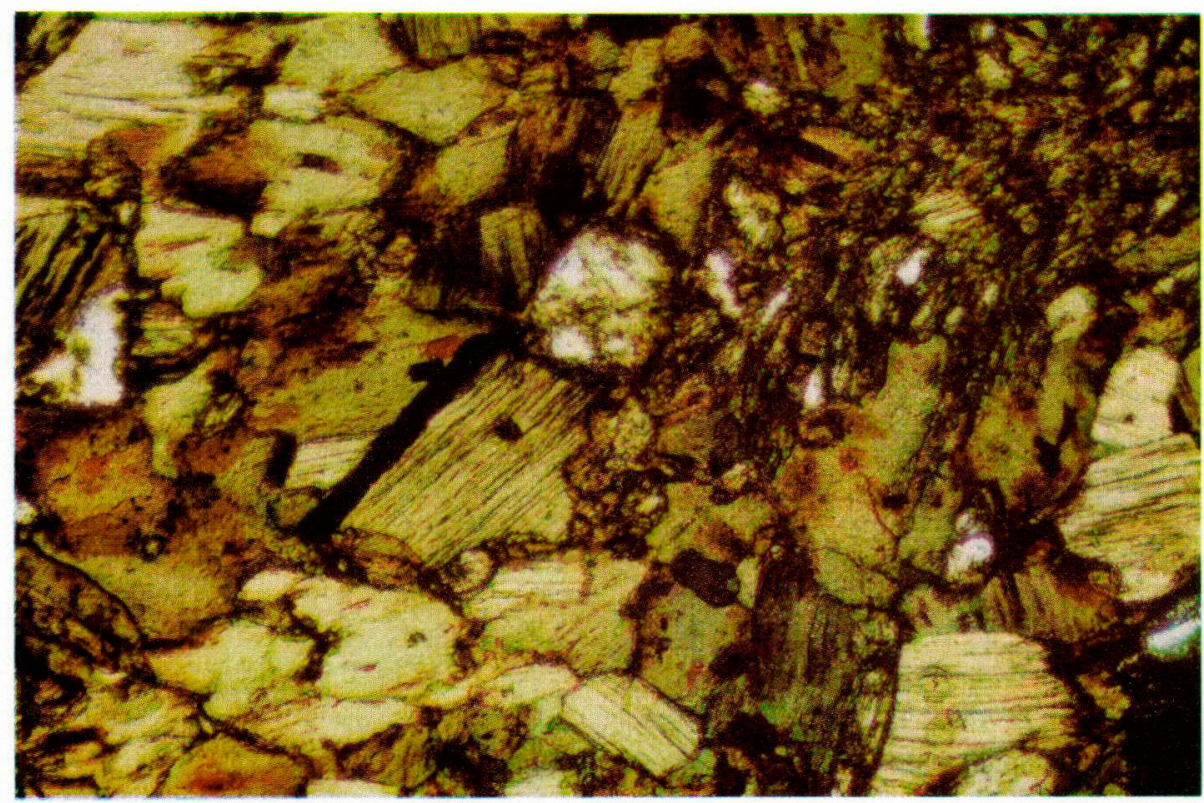

FIG. 4. Thin section photograph of brownish vermiculite. Oxidized iron-rich formation. Drill core 1 , depth $61.6 \mathrm{~m}$. Magnification $90 \times$. Photo E. Halme.

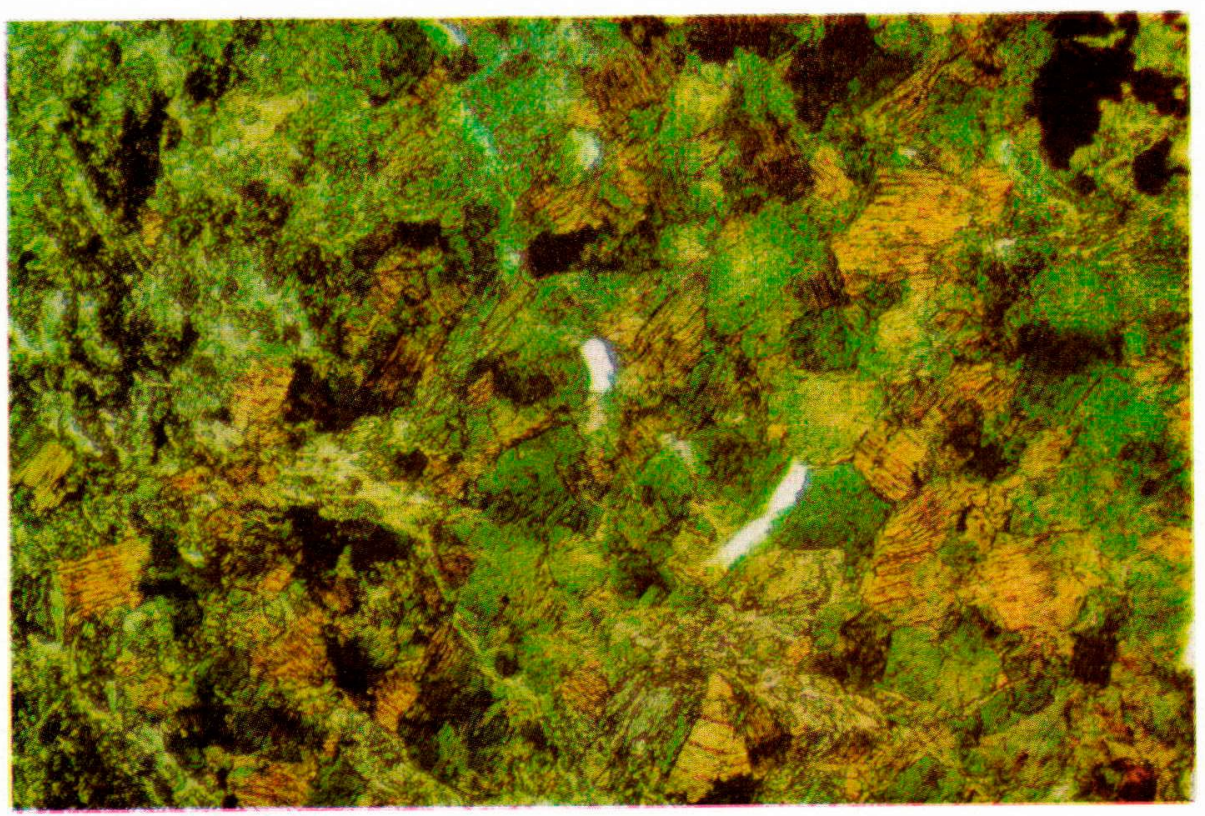

FIG. 5. Thin section photograph of greenish vermiculite. Oxidized iron-rich formation. Drill core 1, depth $73.8 \mathrm{~m}$. Magnification $85 \times$. Photo E. Halme. 
minutes at $600^{\circ}$. With ethylene glycol the $14 \AA$ spacing expands to $16.2 \AA$.

\section{Mica schist.}

The following minerals, listed in their approximate order of abundance, were observed: brown mica, plagioclase, quartz, colourless mica, potash feldspar, ore (coarser opaque), graphite (finer opaque), apatite, tourmaline.

Acknowledgements - In addition to the gentlemen of the Otanmäki Company mentioned in the introduction to this paper, the author wishes to express his gratitude to the following persons of the Geological Survey of Finland: to Mr. Pentti Ojanperä, Mag. Phil,, and Mr Väinö Hoffrén, Mag. Phil., for the rock analyses, to Mr. Jaakko Siivola, Mag. Phil. and Mr. Kauko Laajoki, Mag. Phil., for the electron probe micro-analyses, to Dr. Pentti Ervamaa for the examination of the sulphide minerals, to Dr. A. Vorma for critical reading of the manuscript, to Mr. Erkki Halme for the photos, to Mrs. Elsa Järvimäki and Miss Lea Marjomaa, for the drawings and to Miss Hilkka Kumpunen for the susceptibility measurements.

Finally, the author wishes to thank Professor Vladi Marmo, Director of the Geological Survey, for inspiration and valuable advice during the course of this study.

\section{REFERENCES}

ASTM - Powder diffraction file, sets 1-16. American Society for Testing and Materials.

Deer, Howie and Zussman (1962) Rock-forming minerals, vol. 3, Sheet silicates. Longmans, Great Britain.

Miles, Keith R. (1943) Grunerite in Western Australia. Amer. Mineral., vol. 28, pp. 25-38.

Nuutilainen, J. and Talvitie, J. (1967) Nahkiaisen magneettisen häiriöalueen tutkimukset talvina 1964
1966. Selostus geofysikaalisista tutkimustöistä, geodeettisista mittauksista ja kairauksista. Report of the Otanmäki Company, Oulu.

Pettijohn, F. J. (1949) Sedimentary rocks. Harper and Brothers, New York.

Tyler, Stanley A. (1949) Development of Lake Superior soft iron ores from metamorphosed iron formations. Bull. Geol. Soc. Amer., vol. 60, pp. 1101-1124.

Manuscript received, April 24, 1968. 